\title{
Enhancing service delivery in Joint Admission and Matriculation Board (JAMB) Nigeria: The imperative of e-governance
}

\begin{tabular}{|c|c|}
\hline \multicolumn{2}{|c|}{$\begin{array}{l}\text { Authors: } \\
\text { Emma E.O. Chukwuemeka }{ }^{1} \\
\text { Okeke Chinenye }^{1} \\
\text { Chukwuemeka Okafor }^{2}\end{array}$} \\
\hline \multicolumn{2}{|c|}{$\begin{array}{l}\text { Affiliations: } \\
{ }^{1} \text { Department of Public } \\
\text { Administration, Nnamdi } \\
\text { Azikiwe University, Nigeria }\end{array}$} \\
\hline \multicolumn{2}{|c|}{$\begin{array}{l}{ }^{2} \text { Department of Government } \\
\text { and Public Administration, } \\
\text { Baze University, Nigeria }\end{array}$} \\
\hline \multicolumn{2}{|c|}{$\begin{array}{l}\text { Corresponding author: } \\
\text { Emma Chukwuemeka, } \\
\text { ee.chukwuemeka@unizik. } \\
\text { edu.ng }\end{array}$} \\
\hline \multicolumn{2}{|c|}{$\begin{array}{l}\text { Dates: } \\
\text { Received: } 03 \text { July } 2018 \\
\text { Accepted: } 07 \text { Aug. } 2018 \\
\text { Published: } 29 \text { Nov. } 2018\end{array}$} \\
\hline \multicolumn{2}{|c|}{$\begin{array}{l}\text { How to cite this article: } \\
\text { Chukwuemeka, E.E.O., } \\
\text { Chinenye, O. \& Okafor, C., } \\
\text { 2018, 'Enhancing service } \\
\text { delivery in Joint Admission } \\
\text { and Matriculation Board } \\
\text { (JAMB) Nigeria: The } \\
\text { imperative of e-governance', } \\
\text { Africa's Public Service } \\
\text { Delivery and Performance } \\
\text { Review 6(1), a240. } \\
\text { https://doi.org/10.4102/ } \\
\text { apsdpr.v6i1.240 }\end{array}$} \\
\hline \multicolumn{2}{|c|}{$\begin{array}{l}\text { Copyright: } \\
\text { C 2018. The Authors. } \\
\text { Licensee: AOSIS. This work } \\
\text { is licensed under the } \\
\text { Creative Commons } \\
\text { Attribution License. }\end{array}$} \\
\hline \multicolumn{2}{|l|}{ Read online: } \\
\hline 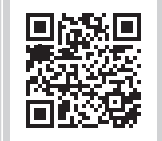 & $\begin{array}{l}\text { Scan this QR } \\
\text { code with your } \\
\text { smart phone or } \\
\text { mobile device } \\
\text { to read online. }\end{array}$ \\
\hline
\end{tabular}

Background: Public service delivery in Nigeria is characterised by inefficiency. To address this administrative imbalance, various government organisations in Nigeria adopted e-governance to improve performance and service delivery.

Aim: The study examined the impact of e-governance on service delivery using Joint Admission and Matriculation Board (JAMB) South East Nigeria as the case study.

Setting: Five states of the South East of Nigeria were studied.

Methods: Descriptive research typology was adopted. Focus group discussion, questionnaire and face-to-face interview were the major tools used for data collection. Statistical tools such as frequency tables and correlation coefficient test were used in data analysis and test of hypotheses.

Results: The correlation coefficient test revealed, among others, that e-governance indicators have significant effect on service culture in JAMB. There is also significant relationship between e-governance and service quality in JAMB. In light of these findings, major recommendations were proffered, some of which are that public sector agencies should as a matter of policy develop a positive service culture and set up e-governance implementation committees that will work out modalities for effective implementation of the concept with performance evaluation.

Conclusion: JAMB and other public agencies should avail themselves of the windows of opportunities that e-governance provides.

\section{Introduction}

The use of e-governance among many countries of the world is premised on its perceived capabilities to facilitate efficient service delivery to the public. The primary benefits of e-governance include efficiency and its capabilities to reduce corruption through automation. InfoDev and the Center for Democracy and Technology (2002) stated that e-governance has the potential to reduce income disparities between countries as well as to promote tourism among other national benefits (Awoleye 2008, Olaitan 2015).

The realisation of the potential of information and communication technology (ICT) and, by extension, e-governance towards empowering the citizenry and improving public service delivery in this digital age led to the formulation of the national policy on information technology in 2001 by the General Olusegun Obasanjo-led Federal Government of Nigeria (Awoleye 2008). The policy details the roadmap for achieving ICT capabilities in the country by 2005 (Face, 2007, 2005, Chukwuemeka et al 2017). As a sequel to the above, a formal focus on e-governance as a means of improving public service delivery could be said to have existed for at least one and a half decades and its appraisal is necessary with a view to understanding its impact on public service delivery in the country. To this end, this study is aimed at assessing e-governance and public service delivery using the Joint Admission and Matriculation Board (JAMB) as a case study. Moreover, the printing of examination slips, the checking of results that often involved long distance travelling with its associated risks, checking of admission status and printing of admission letters can now be easily done in the confines of a candidate's room on the JAMB portal. This eliminates unnecessary travelling, queuing and exposure of adolescents that dominate candidacy of JAMB examination to undue risks. This was not so in the past when all these services were enjoyed only by visiting a designated JAMB office.

The adoption of e-governance in the internal operations of the organisation, however, remains unclear to the public and also has not yet been empirically studied (to the best of the knowledge 
of the researcher having reviewed the extant literature relevant to the subject matter). This creates a vacuum in knowledge which this study intends to fill.

\section{Statement of the problem}

Public service delivery in Nigeria is characterised by inefficiency (Ibietan 2013; Nweze 2010). In a study conducted by Darma and Ali (2014) (Joppe 2000, Lau 2003), clear differences were identified between expectation of service delivery from public servants, officially and the perception of the service quality actually delivered. In order to ensure that the Nigerian public sector agencies are efficient in achieving government's policy objectives, it has become imperative to investigate the nature of e-governance and service delivery in the country. This is particularly important because in the Nigerian public service the issue of poor quality of service delivery, poor service culture, cases of poor employee engagement and cases of negative customer experience that have hindered public service delivery in the country have been reported (Cetina 2009, Mapira 2013).

Many other factors have been identified as the immediate and remote causes of the public service inefficiency, which include nepotism, red-tapism and poor monitoring mechanisms. Some authors have identified the structure of government as the primary cause of the inefficiency. This school of thought argued that in a situation where the government is practically centralised as opposed to the federalism provided in the constitution, effective monitoring becomes a task, leading to inefficient service delivery.

Services such as education, health, agriculture, water and sanitation, power, housing and urban development, justice and defence are prerogatives of the government in Nigeria because of its large resources and relatively less developed private sector. Of particular interest in this array of public sector services is education. Education is unarguably the bedrock of any society and quality of human resource is often cited as crucially linked to the development potential of a nation state like Nigeria (Sharif \& Abdullah 2013, Wagner \& Harter 2006, Layne \& Lee 2001).

Traditionally, JAMB had conducted its examinations using the paper-pencil test (PPT) model. This mode of examination is reportedly characterised by inefficiency and inaccuracy (Retnawati 2015). Although the alternative computer-based test (CBT) has its own challenges, these challenges are primarily related to technology failure Awoleye (2008) (Lawal 2013, Olaopa 2014), which can be rectified easily with state-of-the-art facilities. This is unlike the problem of the PPT that is shrouded in design (Chandler \& Emmenuella 2004, Retnawati 2015).

The inefficiency of the JAMB PPT examination was evident in the wide-scale examination mal-practices that often characterised the conduct of the examination in the past (Oyedeji 2016). As part of the efforts to curb the widespread examination mal-practices, JAMB introduced a customised answer sheet in 1994 on which a candidate's examination numbers and subject types are preprinted (Ojerinde 2015). The examination system was further improved in 1998, involving reshuffling of question types and candidates' seat numbers such that candidates sitting in close proximity cannot copy from one another.

Although the newly introduced measures reportedly curbed the mass cheating in the examination to some extent (Fleming \& Asphind 2007, Ojerinde 2015), inefficiency in grading and corrupt collaborations at the examination centres with officials to undermine the system were still pervasive, necessitating a new model for the examinations. Within the period that JAMB introduced the innovation, Omobola (1995) and Isreal (1996) reported cases of missing results, candidates having wrong types given to them as against the type printed on their answer sheets and similar issues leading to frustrations.

Apart from cheating, the release of results could take months with candidates waiting. This usually put some candidates' life plans on hold as they await the 'verdict' of JAMB to determine their next courses of action. The waiting of thousands of candidates constitutes economic loss to the nation. The mass cheating and the inefficiency in the JAMB require a paradigm shift in strategies towards repositioning the agency for better performance. To this end, the idea of a combined exam of PPT and CBT was formed. Later, the CBT examination mode was fully adopted by JAMB. This gave birth to the adoption of e-governance (at least e-application element of e-governance) (Gentile et al. 2007; Kahn 1990)

It is important to understand how JAMB's service delivery has fared in the use of e-governance. For instance, the use of technology by JAMB in interacting with other government agencies like National Youth Service Corps, National University Commission, etc. - otherwise referred to as government to government (G2G) - which is important for efficient service delivery remains unclear. Likewise, the use of technology in its internal workings among employees Government to Employee (G2E) is also not open to the public and has yet to be empirically assessed.

Furthermore, e-governance is often misconstrued as just the presence of government agencies or institutions on a static website online (Gilber et al 2004, Ohiole \& Ojo 2015, Garson 2006). In as much as government's or its agencies' presence on the Internet via websites (static) is a good step towards e-governance, it is grossly misleading to refer to mere possession of websites as a definition of e-governance. This study will assess JAMB's position with regard to e-governance and public service delivery.

\section{Purpose of the study}

The purposes of the study were the following:

- To investigate the effect of e-governance on service culture in JAMB.

- To examine the relationship between e-governance and service quality in JAMB. 


\section{Research questions}

The following research questions were addressed by the study:

- To what extent does e-governance have significant effect on the service culture in JAMB?

- Is there any relationship between e-governance and service quality in JAMB?

\section{Hypotheses}

The following hypotheses arose from the discussion of the study:

- E-governance has no significant effect on the service culture in JAMB.

- E-governance has no significant effect on employee engagement in JAMB.

\section{Review of related literature Conceptual framework}

\section{E-governance}

The extant literature on e-governance shows that there are different meanings and scope of the concept. While some viewed it as a semblance of e-commerce focused on government customers excluding the e-democracy aspect (Clift 2003, Czarnowsky 2008, Flemmings \& Asplund 2007), others construed it as a virtual reality with interface that provides a medium for governance in a multidimensional form (Torres, Pina \& Royo 2005). Many others have different or related meanings for the concept.

Chatfield and Alhujran (2009, Golpasany 2009) defined e-governance as the 'rapidly emerging global phenomenon of the use of ICT as the new way forward in public administration'. Gopalaam (2009) and Naz (2009) defined it as 'the application of ICT to the government processes to bring Simple, Moral, Accountable, Responsive, and Transparent (SMART) governance'. Basu (2004:15) viewed e-governance (e-government) as:

the use of information technology to free movement of information to overcome the physical bounds of traditional paper and physical based systems' to 'the use of technology to enhance the access to and delivery of government services to benefit citizens, business partners and employees (Alshehri \& Drew 1972, Chandler \& Emmanuells 2002:15)

According to Sithole and Van der Waldt (2016) and Ifinedo (2004), e-governance, which also means electronic governance generally, refers to the use of ICT in order to provide different government services. It enables the exchange of different kinds of communication besides ensuring effective communication of different kinds of transactions. At the same time, it enables the integration of different stand-alone systems and services between the government and the customers and the government and businesses (Karim 2002).

E-governance refers to the usage of information communication technologies for carrying out different public services (Okafor, Fatile \& Ejalonibu 2014). This mainly refers to the application of the Internet so as to ensure that different kinds of services are offered in a manner that is convenient, cost-effective and customer oriented. E-governance also refers to the adoption of IT for enhancing working of the government. It is mainly aimed at the achievement of moral, simple, responsive, accountable and transparent governance (Abasilim \& Edet 2015; Okafor, Fatile \& Ejalonibu 2014). According to Karim (2015), e-governance is a major tool, which is being adopted in order to ensure that there is a highly effective and efficient public service delivery.

A cursory look at the comparative assessment of the e-administration, e-government and e-governance shows that e-governance depicts the maturity stage of electronic service delivery of governments and/or its agencies. The e-governance mirrors a true virtual government where key activities of governance are done electronically. It also appears from the comparison that e-government and e-administration are concerned with putting in place the necessary e-governance while e-governance covers the e-readiness, full e-service delivery as well as continuous improvement on the e-service (see Figure 1).

Al-Omari (2006), International Review of Law and Computer (2004), identified three important aspects of e-government initiatives. He termed these initiatives as improving government processes, connecting citizens and building interactions with and within civil society'. The improvement in government processes is construed as encompassing cutting process costs, managing process performance, making strategic connections in government and creating empowerment within the government architecture. This is a preparatory action for making ground for effective e-governance. To this end, Griffin, Trevorrow and Halpin (2007, Gilbat et al. 2004, Hinedo 2004) suggested that that e-governance should emphasise improvement in service delivery to the citizens rather than automation. This is because mere automation may still be prone to existing inefficiency in service delivery, necessitating a critical assessment of existing infrastructure, framework and processes with a view to removing inefficiency towards e-readiness.

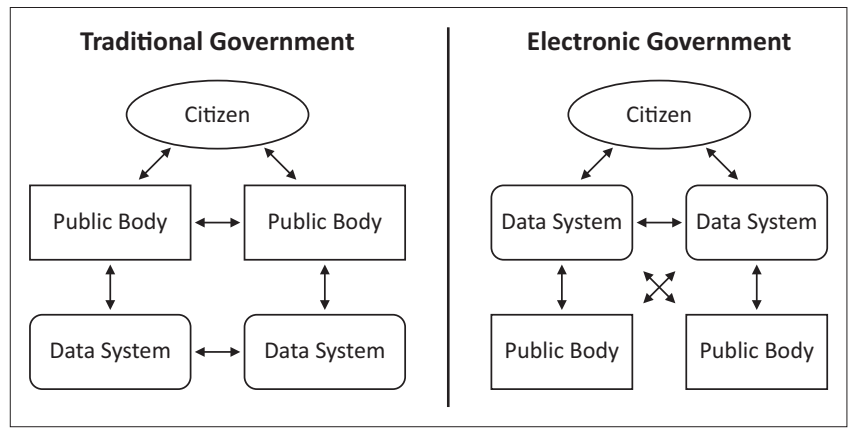

Source: Arifoğlu, A., 2004, E-Governance Implementation in Asia: Problems and Prospects, p. 99, Vani Publishers, Delhi.

FIGURE 1: Traditional versus electronic governments. 


\section{Public service delivery}

According to International Review of Law Computer and Technology (2004) public service is described as the direct and indirect services provided by a government to its nationals or residents within a country. Government provides public service directly by engaging in production, distribution or service and indirectly by financing services rendered to the citizenry by third parties. Governments control the resources of the people and are duty-bound to render services that benefit the people albeit in varying degrees. The extent of involvement of government in service delivery to the masses often corresponds to the economic system in use. While the private sector dominates service delivery in a capitalist economic system, the government is the dominant figure in a socialist economy. For a mixed economy like Nigeria, both the private sector and government provide services substantially to the general public. In Nigeria, government constitutes the major service provider through the public service. The public service refers to all organisations that exist as part of government machinery for delivering services that are of value to the citizens.

According to Oronsaye (2010, Cetoma 2009, Anthonella, Benard and Pace 2017), public service delivery can be seen as 'the process of meeting the needs of citizens through prompt and efficient procedures'. This implies that the interaction between government and citizens should happen in a way such that the needs of the citizens are met in a timely manner, thereby making the citizens key in public service delivery. The implication here is that as the private sector considers its customer as 'king', thereby ensuring quality service delivery, the public should be regarded as 'master' and the beneficiary of enhanced performance of the public service (Aladegbola \& Jaiyeola 2016). Acceptable service delivery can be seen as one of the core responsibilities for the establishment of public organisations. It is identified as 'one of the key functions of the public sector' (Mitel 2007). Okafor, Fatile and Ejalonibu (2014) see public service delivery as the result of the intentions, decision of government and government institutions, and the actions undertaken and decision made by people employed in government institutions'. They posit that it is 'the provision of public goods or social (education, health), economic (grants) or infrastructural (water, electricity) services to those who need (or demand) them' (see Figure 2).

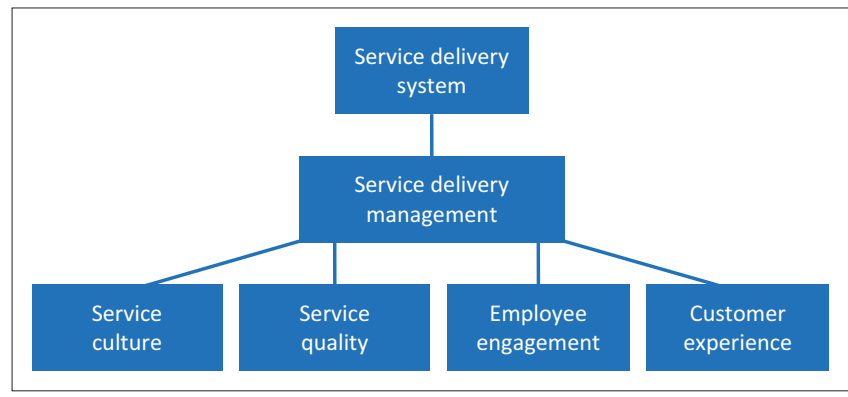

Source: Adapted from ISS Group, 2015, Group Annual Reports, viewed on 05 July 2017, from www.annualreport.issworld.com/2015/

FIGURE 2: Key elements or components of service delivery.

\section{Service culture}

Service culture is considered to be a value creation mode for the company as well as the customer (Ostrom 2010). Although the significance of service culture is known, there is a lack of understanding of current conceptual models referring to diverse service perspectives (Davis 2013). This demonstrates the need to construct and cultivate service value and move from product-based logic to service dominant logic (Brodie 2009 as cited in Davis 2010). Ostrom (2010), Cooper and Shirdler (2003), and Chang (2008) argue that service culture is a basic mode for creating value for service organisations as well as their customers. At present there is a lack of proof to draw the attention of the supplier to the need for service practice and culture.

This led to the discussion by Edvardsson and Enquist (2006 cited in Davis 2010), who stated that changes in 'the service process must be understood and accepted by both employees and the users/customers'. This should result in ongoing training for customers and employees, which would help them to understand and carry out the innovative concept of service.

Along with the training, as pointed out by Lytle and Timmerman (2006), rewards should be provided for servicegiving behaviours and for creating and delivering service excellence. 'This also helps customers to be service cocreators' (Lusch, Vargo \& O’Brien 2007 cited in Davis 2010), encouraging service transformation by adapting new ways of service or innovating for fostering a positive service climate (Liao \& Chuang 2007). It would also help to build a strong association with the clientele, leading to improved quality and service climate, which would be enhanced through service orientation (Gronroos 2006). Service orientation predetermines the handling of a service encounter (employee-customer interaction). Patricio (2011) also mentions that a service system consists of technology, people and other resources in different phases of service to help co-create value.

Antonacopoulou and Kandampully (2000) argue that as the revolution of culture change begins, suppliers focus their attention on outside demand and try to relate it to their inhouse requirements.

Even Edvardsson and Enquist (2006) point out that during big transactions firms need to concentrate on transforming their principal mission of serving their main clients and their in-house culture can fulfil the rest of the requirements. Also the authors emphasise that, although 'external pressure is important for continuous quality improvement', it may lead to a fear of change which can prevent service culture transformation (Davis 2010, Gberevbie et al. 2015).

Kupers (1998) cited in Davis (2010) notes that such disturbing sentiments will disturb the appearance of the service and also the service sharing relations between the client and the firm. This could lead to a drastic change being imposed on a firm's 
capability to build and sustain a service culture through the progress of employees, their service frame of mind and inculcating knowledge and a service focus during the transformation of the firm (Ostrom 2010).

Davis and Gautam (2011) in their study have focused on service culture as an interconnected progression shaping the recruiting, training and rewarding of human resources activities. They have also represented service culture as a service framework for a product-service-based organisation. In addition, their study has shown that through employee and customer knowledge an organisation gets developed.

In their study, Ostrom (2010), Chukwuemeka et al. (2015), and Francis and Ojo (2013) have indicated that to develop and maintain a service culture, it should be based on four key principles:

- recruiting, training and rewarding

- developing a service mindset in product-focused organisations

- creating a learning service organisation by harnessing employee and customer knowledge

- keeping a service focus as the organisation grows and evolves.

Once a superior service delivery system and a realistic service concept have been established, there is no other component so fundamental to the long-term success of a service organisation as its culture (ISS 2015).

\section{Interface between e-governance and service delivery}

E-governance has finally arrived in Nigeria and is imbibed by many public organisations to foster service delivery. Events, seminars and conferences are being organised for various public officers of varying categories so as to evolve appropriate e-governance models that will help them work effectively. At the ground level too, a number of steps are being taken to turn the traditional analogue government into a digital government. Government officials in Nigeria are under pressure to perform and innovate in order to make some difference in the quality of administration and delivery of services to the citizens.

In the midst of such hectic activity going around all of us, we, engaged in the academia, government and the industry, all need to ensure that e-education is properly inculcated in examinations in Nigeria.

The subject of e-governance, argue Ezeani (2017) and Fatile (2012) has become fairly advanced, yet it is continuously evolving. We decided on evolving a set of different value propositions, which would put the users and customers at the pivot of all the knowledge that we wanted to share. To say the least, e-governance offers an opportunity to change the mast of a ship for changing its direction. But it depends on how the politicians and administrators look at this opportunity and the internal and external pressures working on them to bring about changes in the sociopolitical administrative systems. Human beings love inertia and unless there is an inflection point reached under societal pressure, things will continue the old way and the pace of change will be slow. Therefore, it is the duty of different stakeholders, namely the users, citizens, non-governmental organisations (NGOs) and others, involved in e-governance to work as pressure groups for the government to enhance service delivery and service quality.

The application of the new and powerful Internet technology that we can visualise now will vastly change in the years and decades to come, as people in the government and outside give it more freedom to operate. After all, after electricity was invented, it took 40 years to re-organise our workplace. Surely, one day we will realise the vision of one-government, where citizens, government and government to government or any other relationship will merge into a single framework. Data sets will be one, which can be used, transferred and corrected throughout the value chain in a secure environment. For example, tax payers will be required to file a single set of information and all taxation authorities at the central, state and municipal governments would be sharing the database to carry out their own individual functions, under different sets of laws (see Figure 3).

Joint Admissions and Matriculation Board
Official logo
Acronym
Type
Knowledge/skills tested
Purpose
Year started

FIGURE 3: Public Sector: Joint Admissions and Matriculation Board JAMB, Joint Admission and Matriculation Board; Senior School Certificate Examination (SSCE). 


\section{Methodology}

The research design adopted in this study is descriptive survey typology. In the survey, the researcher does not have control of the independent variables because they have already occurred (Stone 2006). If it is possible for the researcher to have experimental and control groups, the appropriate research design would have been an experiment and not a survey (Padsakoff \& Dalton 1987). In the oral interview, the research questions are asked as open-ended questions.

\section{Method of data collection}

Questionnaire, face-to-face interview, observation and focus group discussion were the main tools used in data collection.

\section{Population of the study}

The population of the study comprises all JAMB employees, including the individuals in charge of the JAMB ICT resources in the five South Eastern states of Nigeria, with a total number of 110 staff as follows: Abia State Office (17), Anambra State Office (18), Ebonyi State Office (15), Enugu Zonal Office (30), and Imo Zonal Office (30).

\section{Determination of sample size}

As the total workforce of all the JAMB employees in the five South Eastern states of Nigeria is 110, the entire population was studied.

\section{Data analysis}

The method of item statistics was used for data analysis (see Table 1). Item statistics can be referred to as item-by-item analysis. A mean less than 3.0 implies disagree and a mean greater than 3.0 implies agree with the statement.

\section{Measure of e-governance in Joint Admission and Matriculation Board E-governance}

E-governance is measured through seven question items relating to e-governance (items 6-12) that were included in the questionnaire with a five point Likert scale: disagree (1), strongly disagree (2), not sure (3), agree (4) and strongly agree (5). The average scale of the responses of the respondents represents the rating of e-governance which was used to assess the level of e-governance.

From Table 1, question 6 on the use of interactive website to pass and receive information by JAMB, the weighted mean

TABLE 1: Standard deviation statistical analysis.

\begin{tabular}{|c|c|c|c|c|c|}
\hline Item number & Item & Mean & Standard deviation & $N$ & Remark \\
\hline 6 & Use of interactive website to pass and receive information. & 4.0111 & 0.38202 & 90 & Agree \\
\hline 7 & Investment in Internet backbone and ICT infrastructure development. & 3.7556 & 0.70808 & 90 & Agree \\
\hline 8 & Use of information technologies (Wide Area Networks, the Internet and mobile computing, etc.) in offices. & 3.5889 & 0.88552 & 90 & Agree \\
\hline 9 & Availability of knowledgeable, skilled and ICT-compliant staff. & 3.9333 & 0.66704 & 90 & Agree \\
\hline 10 & Availability of appropriate software for Internet connectivity and e-infrastructure. & 3.7667 & 0.82175 & 90 & Agree \\
\hline 11 & Existence of appropriate ICT legal and government support. & 3.8222 & 0.64613 & 90 & Agree \\
\hline 12 & $\begin{array}{l}\text { Operational use of ICT in the internal processes and activities (memos/mail distribution, employee salaries and } \\
\text { emoluments, staff training, etc. }\end{array}$ & 3.9000 & 0.65429 & 90 & Agree \\
\hline 13 & I conduct my affairs in a manner capable of engendering public trust. & 3.9889 & 0.78604 & 90 & Agree \\
\hline 14 & Corrupt practices and abuse of administrative processes have reduced in the service of JAMB. & 4.0444 & 0.88573 & 90 & Agree \\
\hline 15 & I am consistent at my duty post until close of work. & 3.5000 & 1.07317 & 90 & Agree \\
\hline 16 & Workers exhibit courtesy in delivering services. & 4.0889 & 0.51154 & 90 & Agree \\
\hline 17 & I report for work on time. & 3.3889 & 1.06733 & 90 & Agree \\
\hline 18 & I see a career path in my present job. & 3.3333 & 1.00560 & 90 & Agree \\
\hline 19 & I am dedicated to work and emphasise services quality. & 3.5000 & 1.07317 & 90 & Agree \\
\hline 21 & My approaches in attending to the public suggest that I am inclined towards offering people oriented service. & 3.3333 & 1.00560 & 90 & Agree \\
\hline 22 & My work orders are completed on time. & 3.9111 & 0.64728 & 90 & Agree \\
\hline 23 & Services are performed according to specifications. & 3.7667 & 0.94868 & 90 & Agree \\
\hline 24 & I find personal meaning and fulfilment in my work. & 4.0556 & 0.70887 & 90 & Agree \\
\hline 25 & I am willing to work extra hours to complete a task. & 3.6667 & 1.11174 & 90 & Agree \\
\hline 26 & It is difficult to detach myself from my work. & 2.3556 & 1.18332 & 90 & Disagree \\
\hline 27 & I will stay with JAMB even if I am offered a comparable position with greater pay and benefits elsewhere. & 2.3556 & 1.18332 & 90 & Disagree \\
\hline 28 & My job inspires me to put in my best at work. & 3.8889 & 0.56973 & 90 & Agree \\
\hline 29 & I am enthusiastic about achieving my personal best at attending to visitors and users of JAMB services. & 3.8889 & 0.77088 & 90 & Agree \\
\hline 30 & JAMB offers services that can be tailored to my specific needs. & 3.8778 & 0.95785 & 90 & Agree \\
\hline 31 & I have availability of services round the clock at JAMB. & 3.7111 & 1.04122 & 90 & Agree \\
\hline 32 & I have ease of getting issues or complaints resolved. & 3.5667 & 1.02825 & 90 & Agree \\
\hline 33 & JAMB staffs have positive attitude and are knowledgeable in their job. & 3.7778 & 1.03617 & 90 & Agree \\
\hline 34 & Customer and corporate objectives can be integrated to achieve better service delivery. & 3.9889 & 0.78604 & 90 & Agree \\
\hline
\end{tabular}

$\mathrm{ICT}$, information and communication technology; JAMB, Joint Admission and Matriculation Board.

As shown in Table 2, the respondents agree with all the items except items 26 and 27. 
TABLE 2: Summary of item statistics.

\begin{tabular}{lccccccc}
\hline Items & \multicolumn{2}{c}{ Mean Minimum Maximum Range } & $\begin{array}{c}\text { Maximum } \\
\text { or minimum }\end{array}$ & Variance & $\begin{array}{c}\text { Number } \\
\text { of items }\end{array}$ \\
\hline Item means & 3.686 & 2.356 & 4.089 & 1.733 & 1.736 & 0.178 & 30 \\
$\begin{array}{l}\text { Item } \\
\text { variances }\end{array}$ & 0.774 & 0.146 & 1.400 & 1.254 & 9.595 & 0.125 & 30 \\
\hline
\end{tabular}

value is 4.0111, showing that the respondents agreed that JAMB has an interactive website which it uses to pass and receive information.

For question 7 on investment in Internet backbone and ICT infrastructure development, the weighted mean valve is 3.7556, showing that the respondents agreed that JAMB had invested to acquire Internet backbone and ICT infrastructure development does have other means of sharing information with other government agencies electronically.

For question 8 on the use of information technologies (Wide Area Networks, the Internet and mobile computing, etc.) in offices, the weighted mean value is 3.5889 , showing that the respondents agreed that information technologies were being used in JAMB offices.

For question 9 on the availability of knowledgeable, skilled and ICT-compliant staff, the weighted mean valve is 3.9333, showing that the respondents confirm the availability of knowledgeable, skilled and ICT-compliant staff in JAMB.

For question 10 on whether there is availability of appropriate software for Internet connectivity and e-infrastructure, the weighted mean value is 3.7667 , showing that the respondents agreed that there is appropriate software for Internet connectivity and e-infrastructure in JAMB.

For question 11 on whether there exists appropriate ICT, legal and government support, the weighted mean value is 3.8222 , showing that the respondents agreed that there exists appropriate ICT, legal and government support in the use and development of ICT in JAMB.

For question 12 on whether there exists an operational use of ICT in the internal processes and activities of JAMB, the weighted mean valve is 3.9000 , showing that the respondents agreed that there exists an operational use of ICT in the internal processes and activities of JAMB like memos or mail, distribution, employee salaries and emoluments, staff training, etc.

\section{Measure of service culture in Joint Admission and Matriculation Board Service culture}

To measure service culture, six question items relating to service culture (items 13-18) were drafted in the questionnaire with a five point Likert scale: disagree (1), strongly disagree (2), not sure (3), agree (4) and strongly agree (5). The average scale of the responses of the respondents represents the rating of service culture which was used to assess the level of service culture.
From Table 1, for question 13 on whether conduct is capable of engendering public trust, the weighted mean value is 3.9889, showing that the respondents agreed that they conduct their affairs in a manner capable of engendering public trust.

For question 14 on whether corrupt practices and abuse of administrative processes have reduced, the weighted mean value is 4.0444 , showing that the respondents agreed that corrupt practices and abuse of administrative processes have reduced in the services of JAMB.

For question 15 on whether respondents are consistent at duty post until closing hour, the weighted mean value is 3.5000 , showing that the respondents agreed that they are consistent at their duty post until the close of work.

For question 16 on whether JAMB workers exhibit courtesy in delivering services, the weighted mean value is 4.0889 , showing that the respondents agreed that workers exhibit courtesy in delivering services.

For question 17 on whether JAMB workers report to work on time, the weighted mean value is 3.3889 , showing that the respondents agreed that they report to work on time.

For question 18 on whether respondents see career path in their job, the weighted mean value is 3.3333 , showing that the respondents agreed that they see career path in their job.

\section{Measure of service quality in Joint Admission and Matriculation Board}

\section{Service quality}

To measure service quality, five question items relating to service quality (items 19-23) were included in the questionnaire with a five point Likert scale of disagree (1), strongly disagree (2), not sure (3), agree (4) and strongly agree (5). The average scale of the responses of the respondents represents the rating of service quality which was used to assess the level of service quality.

From Table 1, for question 19 on whether respondents are dedicated to work and emphasise service quality, the weighted mean value is 3.5000 , showing that the respondents agreed that they are dedicated to work and emphasise service quality.

For question 20 on whether JAMB application facilities are convenient for customer use, the weighted mean value is 4.0778 , showing that the respondents agreed that JAMB application facilities are convenient for customer use.

For question 21 on whether respondents' approach of attending to the public is people oriented, the weighted mean value is 3.3333 , showing that the respondents agreed that their approaches in attending to the public suggest that they are inclined towards offering people-oriented services.

For question 22 on whether work orders are completed on time, the weighted mean value is 3.9111 , showing that the 
respondents agreed that their work orders are completed on time.

For question 23 on whether services are performed according to specification, the weighted mean value is 3.7667 , showing that the respondents agreed that they perform their services according to specification.

\section{Test of hypotheses Hypothesis 1}

$\mathbf{H}_{0}$ : E-governance has no significant effect on the service culture in JAMB.

$\mathbf{H}_{\mathrm{a}}$ : E-governance has significant effect on the service culture in JAMB.

For the hypothesis, items 6-11 were used to measure e-governance and items 13-18 were used to measure service culture.

Table 3 shows the available data generated from weighted mean, numbering 1-4. The weighted mean measures E-Governance and Service Culture (see Table 4).

The estimate of $R^{2}$ suggests that all the e-governance variables in the model collectively accounted for over $99 \%$ of the variation in service culture. The $F$ ratio value of 99.058 was significant at less than 0.000 levels. Five out of the seven e-governance indicators had positive signs and significant relationship with service culture.

\section{Decision}

The $F$ ratio as seen above (41.973) is significant at 0.000 levels. The null hypothesis is therefore rejected and the alternate,

TABLE 3: Available data generated from weighted mean.

\begin{tabular}{lcc}
\hline Serial number & E-governance & Service culture \\
\hline 1 & 4.0111 & 3.9889 \\
2 & 3.7556 & 4.0444 \\
3 & 3.5889 & 3.5000 \\
4 & 3.9333 & 4.0889 \\
5 & 3.7667 & 3.3889 \\
6 & 3.8222 & 3.3333 \\
\hline
\end{tabular}

which states that e-governance has significant effect on service culture in JAMB, is accepted.

\section{Hypothesis 2}

$\mathbf{H}_{0}$ : There is no significant relationship between e-governance and the service quality of JAMB.

$\mathbf{H}_{\mathbf{a}}$ : There is significant relationship between e-governance and the service quality of JAMB.

To test this hypothesis, items 6-10 were used to measure e-governance and items 19-23 were used to measure service quality.

Table 5 measured e-governance and service quality using serial numbers 1-5 with weighted mean clearly identified.

\section{Correlations}

The correlation value of 0.717 can be interpreted as strong positive. Then, there exists a strong positive relationship between the variables. The $p$-value of 0.026 shows the existence of enough evidence to reject the null hypothesis and conclude that e-governance has significant relationship with the service quality delivered by JAMB.

\section{Findings}

The findings of this study are as follows:

TABLE 5: Available data generated from weighted mean.

\begin{tabular}{lcc}
\hline Serial number & E-governance & Service quality \\
\hline 1 & 4.0111 & 3.5000 \\
2 & 3.7556 & 4.0778 \\
3 & 3.5889 & 3.3333 \\
4 & 3.9333 & 3.9111 \\
5 & 3.7667 & 3.7667 \\
\hline
\end{tabular}

TABLE 6: Correlations: Relationship between e-governance and service quality.

\begin{tabular}{llcc}
\hline Expunged & Variables & EG & SQ \\
\hline EG & Pearson correlation & 1 & 0.717 \\
& Sig. (2-tailed) & - & 0.026 \\
& $N$ & 5 & 5 \\
SQ & Pearson correlation & 0.717 & 1 \\
& Sig. (2-tailed) & 0.026 & \\
& $N$ & 5 & 5 \\
\hline
\end{tabular}

EG, e-governance; SQ, service quality; Sig., Significance.

TABLE 4: Regression estimates (effect of e-governance on service culture).

\begin{tabular}{|c|c|c|c|}
\hline Model & $\begin{array}{l}\text { Coefficient } \\
\text { estimates }\end{array}$ & $t$-value & Significance \\
\hline (Constant) & 3.947 & 5.626 & 0.000 \\
\hline Use of interactive website to pass and receive information & 0.004 & 0.050 & 0.960 \\
\hline Investment in Internet backbone and ICT infrastructure development & 0.533 & 4.139 & 0.000 \\
\hline Use of information technologies (Wide Area Networks, the Internet and mobile computing, etc.) in offices & 0.361 & 1.722 & 0.088 \\
\hline Availability of knowledgeable, skilled and ICT-compliant staff & 0.258 & 2.190 & 0.031 \\
\hline Availability of appropriate software for Internet connectivity and e-infrastructure & 0.775 & 4.358 & 0.000 \\
\hline Appropriate ICT legal and government support & 0.834 & 10.463 & 0.000 \\
\hline Operational use of ICT in the internal processes and activities (memos/mail distribution, employee salaries and emoluments, staff training, etc. & 1.191 & 11.353 & 0.000 \\
\hline$R^{2}$ & 0.872 & - & - \\
\hline $\operatorname{Adj} R^{2}$ & 0.863 & - & - \\
\hline$F$ & 99.058 & - & 0.000 \\
\hline
\end{tabular}

ICT, information and communication technology. 
- That e-governance indicators have significant effect on service culture in JAMB. This result invalidated the first null hypothesis of the study, which states that e-governance has no significant effect on service culture in JAMB. The $F$ ratio of 99.058 from the regression analysis was found to be significant at 0.000 levels. Therefore, the null hypothesis was rejected, thereby leading to the conclusion that e-governance has significant relationship with employee engagement in JAMB.

- That there is a significant relationship between e-governance and service quality in JAMB. This finding invalidated the second null hypothesis, which states that there is no significant relationship between e-governance and service quality in JAMB. The correlation value of 0.717 can be interpreted as strong positive. Then there exists a strong positive relationship between the variables. The $p$-value of 0.026 shows the existence of enough evidence to reject the null hypothesis and conclude that e-governance has significant relationship with the service quality delivered by JAMB.

\section{Conclusion}

\section{Recommendations}

From the findings of the study, the researchers recommend the following:

- That JAMB should organise training from time to time for its workers to train them on emerging trends in e-governance.

- The organisation should procure more ICT equipment across all JAMB zonal offices across the federation.

- Awareness should be created in higher schools on this trending technological innovations to ensure that students sitting for University Matriculation Tertiary Examination (UMTE) understand the concept of e-governance.

\section{Acknowledgements Competing interests}

The authors declare that they have no financial or personal relationships that may have inappropriately influenced them in writing this article.

\section{Authors' contributions}

O.C. collected data and did data analysis, E.E.O.C. moderated and edited the work and made some useful additions, while C.O. worked on the methodology, findings and conclusion.

\section{References}

Alderfer, C.P., 1972, 'An empirical test of a new theory of human needs', Organizational Behaviour and Human Performance 4(2), 142-175. https://doi.org/10.1016/00305073(69)90004-X

Abasilim, U. \& Edet, D., 2015, Attaining a Better Public Service Delivery Through E-Governance Adoption in Nigeria, Governance and Public Service Delivery in Nigeria 10(2), 45-60.

Alshehri, M. \& Drew, S., 2010, 'Challenges of e-government services adoption in Saudi Arabia from an e-ready citizen perspective', Education 29(5), 1.

Al-Omari, H., 2006, E-Government architecture in Jordan: A comparative analysis, Journal of Computer Science 2(11), 846-852.
Arifoğlu, A., Kman, I., Yazici, A., \& Mishra, A., 2004, E-Government, A global perspective and an empirical assessment of ctitizens attribute, Government Information Quarterly 22(2), 239-257.

Arifoğlu, A., 2004, E-Governance Implementation in Asia: Problems and Prospects, Vani Publishers, Delhi.

Aladegbola, I.A., \& Jaiyeola, F., 2016, Critique of Public Administrative Reform Systems: Post-Independence in Nigeria, Africa's Public Service Delivery and Performance Review 4(1), 35-61.

Antonella, C., Bernard, C. \& Pace, S., 2007, 'Pleasure and enjoyment in the consumption experience: The case of ICT-based Services', in S. Borghini, M.A. McGrath \& C. Otnes (eds.), e-European advances in consumer research, vol. 8, pp. 241-242, Association for Consumer Research, Duluth, MN.

Antonacopoulou, S. \& Kandanipully, R., 2000, 'Emerging barriers in e-governance implementation', International Journal of Electronic Governance 4(3), 47-65.

Awoleye, M., Oluwaranti, A., Siyambola, W. \& Adagunodo, R., 2008, Assessment of e-governance resource use in south-western Nigeria, Proceedings of the $2^{\text {nd }}$
International Conference on Theory and Practice of electronic governance AsCM, International Conference on Theory and Practice of electronic governan
viewed 02 July 2017, from http://dl.acm.org/citation.cfm?id=1509127

Basu, S., 2004, 'E-government and developing countries: An overview', International Review of Law Computer \& Technology 12(1), 109-132.

Brodie, R., 2009, 'Customer engagement conceptual doman, fundamental propositions, and implications for research', Journal of Service Research 14(3), 252-271.

Cetina, K.K., 2009, 'The society for the study of symbolic interaction', Symbolic Interaction 32(1), 61-87. https://doi.org/10.1525/si.2009.32.1.61

Centre for Democracy and Technology, 2002, Annual Report, pp. 34-50, Center for Democracy \& Technology (CDT), Washington, D.C.

Chandler, S. \& Emanuels, S., 2002, 'Transformation not automation', Proceedings of 2nd European Conference on E-government, Oxford, United Kingdom, 24-25 March 2002, pp. 91-102.

Chang, H., 2008, Autoethnography as method, Left Coast Press, Walnut Creek, CA.

Chatfield, A.T. \& Alhujran, O., 2009, 'A cross-country comparative analysis of e-government service delivery among Arab countries', Information Technology for Development 15(3), 151-170. https://doi.org/10.1002/itdj.20124

Chukwuemeka, E.E., Ubochi, E.I. \& Okechukwu, E.U., 2017, 'Effect of e-government on service delivery in federal university Ndufu Alikeikwo, Ebonyi State', Review of Public Administration and Management 5(3), 45-60.

Clift, S., 2003, E-democracy, e-governance and public net-work, viewed 02 July 2017, from http://www.opensourcejahrbuch.de/download/jb2004/chapter_04/IV-5-

Cooper, D.R. \& Schirdler, P.S., 2003, Business Research Methods, $8^{\text {th }}$ edn., McGraw-Hill Irwin, Boston, MA

Czarnowsky, M., 2008, Learning role in employee engagement: An ASTD research study, American Society for Training \& Development, Alexandria, VA.

Darma, N.A. \& Ali M., 2014, An assessment of public sector service delivery in Nigeria: A case study of federal capital territory area councils, 2007-2011, International Journal of Development and Sustainability 3(8), 1756-1776.

Davis, F., 2010, The Substance of E-Learning, Grooton Press, New York, NY.

Davis, W. \& Gautam, M., 2011, Practice of Public Administration in Asia, Vani Publishers, Delhi.

Davis, W., 2015, 'Empirical view of E-Governance in new states: Periscoping Ghana', International Journal of Social Sciences 5(3), 55-67.

Davis, W., 2013, Understanding E-Administration, Eagle Publishers, Los Angeles, CA.

Diso, A., 2005, Fundamentals of E-Government, Vani Publishers, Delhi.

Ezeani, E.O., 2006, Fundamentals of public administration, Snaap Press Ltd, Enugu.

Fatile, J.O., 2012, 'Electronic governance: Myth or opportunity for Nigerian Public administration?', International Journal of Academic Research in Business and Social Sciences 2(9), 122.

Francis, F.N. \& Ojo, A.N., 2013, Challenges and prospects of implementing e-governance in Nigeria: E -prints, viewed 04 August 2017, from Covenant University.edu.ng/5278/1/

Fleming, J.H. \& Asplund, J., 2007, Human Sigma, Gallup Press, New York.

Garson, G.D., 2006, 'Securing the virtual state: Recent development in privacy and security', Social Science Computer Review 24(4), 489-496. https://doi. org $/ 10.1177 / 0894439306289100$

Gberevbie, D., Ayo, C., Iyoha, F., Duruji, M. \& Abasilim, U., 2015, 'E-governance: Strategy for militating non-inclusion of citizens in policy making in Nigeria', 15th European Conference on e-Government, University of Portsmouth, United Kingdom, June 18-19, pp. 25-45.

Gentile, C., Spiller, N. \& Noci, G., 2007, 'How to sustain the customer experience: An overview of experience components that co-create value with the customer', European Management Journal 25, 395-410. https://doi.org/10.1016/j. European Manager
emj.2007.08.005

Gilbert, D., Balestrini, P. \& Littleboy, D., 2004, 'Barriers and benefits in the adoption of e-government', International Journal of Public Sector Management 17(4), 286-301. https://doi.org/10.1108/09513550410539794

Gopalsamy, N., 2009, Information technology and e-governance, New Age International.

Griffin, D., Trevorrow, P. \& Halpin, E.F. (eds.), 2007, Developments in e-government: A critical analysis, IOS Press, Amsterdam.

Gronroos, E., 2008, Government Online, Vani Publishers, Delhi. 
Ibietan, J., 2013, 'Corruption and public accountability in the Nigerian public sector: Interrogating the omission', European Journal of Business Management 5(15), 41-48.

Ifinedo, P.E., (2004) 'e-government-precursors, problems, practices and prospects: A case of Nigeria', in Proceedings of the 2004 International Business Information Management (IBIM) Conference, pp. 1-10, viewed 5 August, 2017, from http:// faculty.cbu.ca/pifinedo/ibimnedo.pdf

Israel, O., 1996, Fundamentals of Communications, Vinez Publishers, Lagos.

ISS Group, 2015, Group Annual Reports, viewed on 05 July 2017, from www. annualreport.issworld.com/2015/

Joppe, M., 2000, 'The Research Process', in N. Galafshani (ed.), Understanding reliability and validity in qualitative research, pp. 597-606, The Qualitative Report 8(4), viewed 25 February 1998, from https://core.ac.uk/download/pdf/51087041.pdf

Joshua, M.T. \& Ikiroma, B., 2012, Computer-based testing in Nigeria's university entrants'matriculation examination: Readiness and acceptability of critical stakeholder, pp. 1-10, Mangroove Publishers, Lagos.

Kahn, W.A., 1990, 'Psychological conditions of personal engagement and disengagement at work', Academy of Management Journal 33(4), 692-724.

Karim, M., 2015, Electronic Governance 3rd ed., Sage Publications, London.

Lau, E., 2003, 'Challenges for e-government development', 5th Global Forum on Reinventing Government, 05 November 2003, OECD e-Government project, pp. 1-18, Mexico City, Mexico.

Lawal, A.W., 2013, 'Technical and vocational education, a tool for national development in Nigeria', Mediterranean Journal of Social Sciences 4(8), 34-45.

Lytle, R. \& Timmerman, J., 2006, 'Service orientation and performance: An organisational perspective', Journal of Services Marketing 20(2), 136-147.

Liao, I. \& Chuang, K., 2007, Managing in a developing Society, Sage Publications, London.

Layne, K. \& Lee, J., 2001, 'Developing fully functional e-government: A four stage model', Government Information Quarterly 18, 122-136. https://doi.org/10.1016/ S0740-624X(01)00066-1

Mapira, S., 2013, Government Online, SST Publishers, New Delhi.

Mitel, T., 2007, E-Governance in Developing Nations, Homemade Publishers, Accra.

Naz, R., 2009, 'E-Governance for Improved Public Service Delivery', Fiji Journal of Service Science and Management 2(3), 190-203.

Nweze, M. \& Chinwe, T., 2010, 'The use of ICT in Nigerian universities, A case study of Obafemi Awolowo University, Ile Ife', Library Philosophy and Practice e-journal 2(3) $45-60$.
Ohiole, M. \& Ojo W., 2015, Elements of Government in Nigeria, Vinez Publishers, Lagos.

Olaitan, A.W., 2015, 'The contributory effects of socio-cultural factors on e-government adoption among Nigerians', Global Journal of Politics and Law Research 3(1), 91-104.

Olaopa, T., 2014, Seminar on sharing success stories and challenges in e-governance/eadministration, viewed 03 August 2017, from http://www.cafrad.org/Workshops/ Tanger21-23_04_14/olaopa.pdf

Okafor, C., Fatile, J. \& Ejalonibu, G., 2014, Public innovations and changing ethics in Africa, Africa's Public Service Delivery and Performance Review 2(4), 46-71.

Ostrom, F., 2010, 'Beyond Markets and States. Polytechnic Governance of Complex Economic Systems', American Economic Review 100(2), 1-33.

Oyedeji, S.O., 2016, 'Educational Assessment in Nigerian Secondary Schools: Historical Analysis, Challenges and Prospects', International Advanced Journal of Teaching and Learning 2(4) 43-54.

Omobola, O., 1995, Theory and Practice of Public Administration in Nigeria, AFP Publishers, Onitsha.

Oronsaye, S., 2010, Galloping Poverty in Nigeria: An Appraisal of Government Interventionist Policies, Publication of the office of Federal Head of Service Abuja No. 3, pp. 17-25.

Ojerinde, B., 2015, Substance of Public Administration in Nigeria, Providence Publishers, Enugu.

Padsakoff, N. \& Dalton, O., 1987, Principles of Government, Sage Publications, London.

Retnawati, H., 2015, 'The Comparison of Accuracy Scores on the Paper and Pencil Testing vs Computer Based testing', TOJET: The Turkish Online Journal of Educational Technology 14(4), 34-43.

Sharif, W., \& Abdullahi, U., 2013, 'Interrogating online government and sustainable development, Journal of Policy and Development Studies 5(4), 60-72.

Stone, O., 2006, Elements of Public Administration, McGraw Hill, New York.

Sithole, B.P. \& Van der Waldt, D., 2016, The fundamentals of information communication technology, Routledge, London.

Torres, L., Pina, V. \& Royo, S., 2005, 'E-Governance and the transformation of public administration in EU countries Beyond NPM or just a second wave of reform?', Online Information Review 29(5), 531-553.

Wagner, R. \& Harter, J.K., 2006, The great elements of managing, The Gallup Organization, Washington, DC

Waldt, N., 2016, Understanding Electronic Government, Sage Publications, London. 